\title{
The Prosthetic Materials in Hernia Repair
}

\author{
Doğan Gönüllü, Ferda Nihat Köksoy \\ Clinic of General Surgery, Gaziosmanpaşa Taksim Training and Research Hospital, İstanbul, Turkey
}

\begin{abstract}
Even though the number and variety of materials used in hernia operations have increased considerably, the ideal mesh is yet to be produced. The aim of this study is to review the current information on available meshes. Literature on the presently used grafts and the means of their usage were reviewed through Medline-PubMed. Large pores of lightweight grafts were shown to decrease the risk of infection and shrinkage. There is still no proven superiority in terms of the materials that are aimed for intra-abdominal use and have one side covered with adhesion preventers. The results prove that hernia surgeries using mesh (graft) provide a better outcome compared with conventional repair methods. Fiber type, tensile strength, and pore width have been indicated as the most important factors in mesh choice as well as determinants of biocompatibility. It is understood that the required tensile strength is less than expected, and lightweight meshes are superior in providing flexibility and comfort. In inguinal hernia repair, lightweight meshes suitable for the hernia type and lightweight or biomeshes that are absorbable in the presence of an infection are considered to be the better choice. Composite meshes that have one side covered in adhesion-preventive barriers are asserted to be the proper fit for the intraabdominal procedures. (JAREM 2015; 5: 1-5)
\end{abstract}

Keywords: Hernia, inguinal hernia, meshes, grafts

\section{INTRODUCTION}

The meaning of prosthesis in ancient Greek is "additional organ". In 1857, Theodore Billroth asserted that "if we could artificially produce tissues of the density and toughness of the fascia and tendon, the secret of radical cure of hernia can be discovered".

Hernia repair is one of the most frequently conducted general surgeries. After Bassini and Shouldice described repair methods using the person's own tissues, Lichtenstein popularized the "tensionless hernia repair" procedure that makes use of the graft. Before long, the preferred approach for inguinal hernia repairs changed, such that $60 \%$ of inguinal hernias and more than $90 \%$ of incisional hernia repairs are now conducted with grafts. Although the widespread use of grafts decreased the relapse rates, it also increased complications such as seroma, wound infection, fistula, chronic pain, and bowel adhesions (1). These complications may be partially due to the body's reaction to foreign objects or may be directly related to the graft technique.

Despite the definition of ideal graft criteria and advancements in technology, an ideal prosthetic product that meets all these criteria is yet to be produced. The industry provides a variety of products for the surgeon. However, there is a lack of literature on most of these products; hence, the claims of their manufacturers cannot be substantiated. Consequently, surgeons must keep track of literature on the usage of surgical patches.

This review study aims to provide information on contemporary grafts and their usage.

\section{METHODS}

Literature on the presently used grafts and the means of their usage were reviewed through Medline-PubMed.

\section{RESULTS}

The silver graft, the first synthetic material used for hernia repair in the early twentieth century, was abandoned for tantalum in the 1940s due to its abrasiveness and the complications it caused. The polyethylene graft was first used by Dr. Francis Usher in $1958(2,3)$. However, in this first use, sterilization problems were recorded for this material.

As the number of reported complications of synthetic meshes increased, a search for new mesh technologies that would be compatible with the body was launched. Despite the lack of consensus on production, meeting the criteria Cumberland and Scales set out in 1952 is still considered essential: 1) The graft should not be physically altered with the influence of tissue fluids, 2) It should be chemically inert, 3) It should not cause inflammatory or foreign object reactions, 4) It should not be carcinogenic, 5) It should not cause allergies or hypersensitivity, 6) It should endure mechanical strain, and 7) It should be sterilizable (4).

\section{Biocompatibility of the Graft}

Even though all modern materials are hypothetically assumed to be biologically inert and nontoxic, when placed in the tissue, they cause a number of reactions (inflammation, fibrosis, infection, and foreign object reaction) with largely unaccounted pathogeneses. Considering experimental studies, it is possible to hypothesize that the foreign object reaction is not a direct result of the material itself. Rather, the material dissolves a part of the surrounding tissue proteins by soaking them in, and the foreign object reaction unfolds against the waste of the dissolved proteins. The foreign object reaction is not solely related to the polymer structure of the graft. Diameters of its pore and fibers, the nature of the tissue it contacts, and whether it is mono- or multifilament is also of importance. Large porous lightweight 
meshes narrow the surface of contact, which decreases the likelihood of foreign object reactions and fibrotic reactions (5).

Advancement in mesh production technologies was initiated by experimental studies aimed at understanding the physiology and mechanics of the abdominal wall as well as research on graft structures that would match the tissue.

As a result of these studies, two types of synthetic graft concepts were developed: small porous heavyweight meshes and large porous lightweight meshes. Hollinsky $(6,7)$ defined these meshes based on their biomechanical qualities:

\section{Lightweight Meshes}

Weight: $33 \mathrm{~g} / \mathrm{m}^{2}(0.5 \mathrm{~g}$ for $15 \times 10-\mathrm{cm}$ area), thickness $<0.5 \mathrm{~mm}$, pore width $>1.0 \mathrm{~mm}$.

\section{Heavyweight Meshes}

Weight: $100 \mathrm{~g} / \mathrm{m}^{2}$ (1.5 g for $15 \times 10-\mathrm{cm}$ mesh), thickness $>0.5 \mathrm{~mm}$, pore width $<1.0 \mathrm{~mm}$.

Many mesh qualities are determined based on the type of processing the fibers undergo: "woven" or "knitted." Woven meshes consist of a single thread, have a looser structure (large pores, flexible), and are not highly resistant. On the other hand, knitted meshes are manufactured by waving a number of parallel fibers and are denser, have smaller pores, and are more resistant. All the knitted products are softer and thicker than woven polypropylene meshes.

Heavyweight meshes are designed for endurance and have high tensile strength and small pores that enable a large area of contact with the tissue and, consequently, cover the defect with a rigid-fragile scar tissue (4-16\% flexibility per $16 \mathrm{~N} / \mathrm{cm})$. The fact that these meshes can limit the movements of the abdominal wall by decreasing the flexibility of the area constitutes a major risk, particularly in large incisional hernia repairs. Lightweight meshes have less tensile force and large pores that provide narrower contact with the tissue, and therefore, these meshes adapt to the nature of the area by covering the defect with a flexible tissue containing less scars (11-32\% flexibility per $16 \mathrm{~N} / \mathrm{cm}$ ) (6).

According to the Laplace law (calculated based on $20 \mathrm{~Pa}$ as the maximum pressure, $100 \mathrm{~cm}$ as the abdominal circumference), theoretical tensile force needed for hernias with a large defect where borders of the fascia cannot be placed such that they face one another is $32 \mathrm{~N} / \mathrm{cm}$. For defect repairs in which the fascia borders could be closed, even $16 \mathrm{~N} / \mathrm{cm}$ is sometimes enough. These calculations prove that a tensile force of $100 \mathrm{~N} / \mathrm{cm}$, a quantity considered to be an advantage for heavy meshes, is redundant (8). Rather, meshes that can endure at least $32 \mathrm{~N} / \mathrm{cm}$ in large hernia (incisional hernia) repairs should be used (8).

Development of polymerized carbon compounds has revolutionized hernia surgery. Innovations that started with the discovery of polypropylene in 1962 have currently arrived to a point where four different nonabsorbable polymer materials (primary absorbable materials are Poliglactin910 and Polyglycolic Acid) are provided (Table 1).

\section{Polypropylene}

It is insoluble, has an acceptable level of biocompatibility, and causes a small amount of the substance reaction and heavy fibrosis. Because they have blue lines that are spread throughout
Table 1. Nonabsorbable graft types (single-layered)

\begin{tabular}{|c|c|c|c|}
\hline Patch & Trade Name & Year & Manufacturer \\
\hline Polypropylene & $\begin{array}{l}\text { Marlex }^{\circledR} \\
\text { Prolene }^{\circledR} \\
\text { Prolene Soft } \\
\text { Surgipro mono/ } \\
\text { multifilament }^{\circledR} \\
\text { Atrium (Prolite) } \\
\text { Parietene }^{\circledR} \\
\text { Premilene }^{\circledR} \\
\text { Biomesh } \\
\text { (A2, P1, P3, P8, P9) } \\
\text { Optilene mesh }^{\circledR}\end{array}$ & 1958 & $\begin{array}{l}\text { Bard } \\
\text { Ethicon } \\
\text { Ethicon } \\
\text { Tyco/USSC } \\
\text { Atrium Medical } \\
\text { Covidiene } \\
\text { Braun } \\
\text { Cousin Biotech } \\
\text { Braun }\end{array}$ \\
\hline Polyester (PET) & $\begin{array}{l}\text { Mersilene }^{\circledR} \\
\text { Parietex }{ }^{\circledR} \\
\text { Dacron } \\
{ }^{\circledR} \\
\text { Biomesh } \\
\text { (A1, A3, 3D) } \\
\text { Biomesh }^{\circledR} \\
\text { (NK1, NK2, NK8) }\end{array}$ & $\begin{array}{l}1956 \\
1993\end{array}$ & $\begin{array}{l}\text { Ethicon } \\
\text { Sofradim } \\
\text { Bard } \\
\text { Cousin Biotech } \\
\text { Cousin Biotech }\end{array}$ \\
\hline ePTFE & $\begin{array}{l}\text { Goretex }^{\circledR} \\
\text { Mycromesh } \\
\text { Biomaterial } \\
\text { Mycromesh }^{\circledR} \\
\text { PlusBiomaterial } \\
\text { (silver carbonate, }^{\circledR} \\
\text { chlorhexidin) }^{\text {MotifMesh }}{ }^{\circledR}\end{array}$ & & $\begin{array}{l}\text { WLGore } \\
\text { WLGore } \\
\text { WLGore } \\
\text { Proxy } \\
\text { Biomedical }\end{array}$ \\
\hline PVDF & DynaMesh IPOM ${ }^{\circledR}$ & & DynaMesh \\
\hline
\end{tabular}

the patch, Prolene Soft ${ }^{\circledR}$ (Ethicon) and Optilene Mesh LP ${ }^{\circledR}$ (Braun) provide technical convenience in laparoscopic hernia repair.

$\mathrm{Ti}^{-M e s h}{ }^{\circledR}$ is a very lightweight, monofilament material with a pore diameter of $>1 \mathrm{~mm}$. It is covered with titanium to increase the compatibility of polypropylene meshes. However, disadvantages are that biocompatibility levels expected to not be met (9) and tensile force is less than $16 \mathrm{~N} / \mathrm{cm}$.

\section{Polyester Poly-Etilen-Tereftalat (PET)}

Its biocompatibility is very good. It causes a lower amount of the foreign object reaction compared with polypropylene. However, it does not stay stable for long, and its polymers are hydrolyzed.

\section{Expanded-Poli-Tetra-Floro-Etilen (ePTFE)}

It was first used as a vein graft in 1972 and was not utilized for hernia repair until 1983. Even though it displays a good level of biocompatibility (pore width: 1-6 mm), particularly in the scar in infections, it may sometimes become torn, and its pieces may cause a foreign object reaction.

\section{PoliVinilden DiFlorid (PVDF)}

It is a very recent polymer that is still in the trial phase.

Due to the disadvantages of PET and ePTFE meshes, most of the new patches are polypropylene based. After 1998, poly- 
propylene-based "hybrid meshes" began to be produced to make the material tissue compatible. In the production of these meshes, the nonabsorbable polypropylene structure percentage is reduced to $30 \%$, and an absorbable part is added (Vicryl ${ }^{\Theta_{-}}$ Polyglactin910 or Monocry| ${ }^{\circledR}$-Polygleocapron 25). In the hybrid meshes of Vypro- $I^{\circledR}$ and Vypro- $I^{\circledR}$, which consist of polypropylene and Poliglactin 910, the width of pores have been increased by $500-600 \%$. Absorbed parts disappear within 6 weeks without any serious foreign object reaction. On the other hand, Ultrapro ${ }^{\circledR}$ is a compound of nonabsorbable polyproylene and absorbable Polyglecapron 25. It is a monofilament and has large pores ( $>3$ $\mathrm{mm})$. The part of it that is added within the first weeks to increase its tensile force dissolves in 56-140 days (10). Polyglecapron 25 exhibits a lesser tissue reaction compared with Polyglactin 910.

The spread of laparoscopic repairs for incisional hernias, considering its ongoing contact with bowels, forced the production of meshes that create minimal adhesions and do not cause fistulation. Taking advantage of the durability of polypropylene meshes, composite materials covered with absorbable or nonabsorbable barriers have been developed (Table 2, 3). In addition to polypropylene, the inner surface is covered with a barrier (carboximetilcelulosa + hyaluronic acid) dissolved in SepraMesh ${ }^{\circledR}$ and PTFE that is nondissolvent in Composix Mesh ${ }^{\circledR}$.

Based on the structure of the hernia defect, "prefabricated prosthetic products" prepared with polypropylene is also available. The first one used for this purpose had plugs with a graft piece that the surgeon had given a cone shape. Even though Gilbert, in 1992, reported that all inguinal hernias were fixed with these plugs (11), it was later understood that the percentage of recurrence due to shrinkage is high. In the following years, more developed products came into the market, such as Kugel Patch ${ }^{\circledR}$ (Bard) (memory mesh), Prolen Herni System ${ }^{\circledR}$ (Ethicon) (a mesh system that is placed to the anterior of the fascia and preperitoneal in two layers), Crura Soft Patch ${ }^{\circledR}$ (Bard) (designed for placement in the peraoesophagal area), Gluca Tex 3D ${ }^{\circledR}$ (Brennen Medial), Ventralex Hernia Patch ${ }^{\circledR}$ (specially designed for the trocar site and umbilical hernia), Parietex Umbilical Patch ${ }^{\circledR}$ (Covidiene).

\section{Biological Meshes}

These types of grafts are a result of biological engineering and are, in fact, developed using a collagen matrix. This structure guides fibroblasts migration and brings out natural "neofascia" in patients. Products such as Surgisis $\mathrm{ES}^{\circledR}$, Portal Perm ${ }^{\circledR}$, Portal Gen ${ }^{\circledR}$, Permacol $^{\circledR}$ are made of swine mucosa, while Alloderm ${ }^{\circledR}$ is made using cadaver tissue. Biomaterials made of acellular dermis are appropriate for infected areas. However, there is currently no evidence indicating that they can be used for routine hernia repairs (8).

\section{Mesh Complications}

Recently, procedures using grafts have become much more common in hernia repair. It should be noted that, if graft use is limited to cases with a weak posterior wall, graft-related side effects could be minimized (12).

\section{Recurrence}

With the use of meshes, recurrence rate has decreased from 17$67 \%$ to $1-32 \%$, particularly in incisional hernia repairs (13). It is observed that the frequency of recurrence is $99 \%$ at an average of 26 months (3-120 months) after the repair of inguinal hernias with
Table 2. Composite grafts with an absorbable component on one side

\begin{tabular}{|l|l|l|l|}
\hline Patch & Trade Name & Year & Manufacturer \\
\hline $\begin{array}{l}\text { Poly-Propylene } \\
\text { based: }\end{array}$ & $\begin{array}{l}\text { Parietene Composite } \\
\text { (Atelocollagen }+ \\
\text { polyethilen glicol) } \\
\text { SepraMesh }\end{array}$ & 2001 & Sofradim Int. \\
& $\begin{array}{l}\text { (Carboximetilcellulosa } \\
\text { +hyaluronic acid) } \\
\text { Gluca Mesh }\end{array}$ & Genzyme \\
(Beta glucan) & Brennen \\
\hline $\begin{array}{l}\text { Polyester } \\
\text { based: }\end{array}$ & $\begin{array}{l}\text { Parietex Composite } \\
\text { (Atelocollagen }+ \\
\text { polyethilen glicol) }\end{array}$ & & Sofradim Int. \\
\hline
\end{tabular}

Table 3. Composite grafts with nonabsorbable components on both sides

\begin{tabular}{|c|c|}
\hline Trade Name & Manufacturer \\
\hline Composix ${ }^{\circledR}$, Composix Ex ${ }^{\circledR}$ & Bard \\
\hline (Poly-Propylene + ePTFE) & \\
\hline $\begin{array}{l}\text { Dual Mesh }{ }^{\circledast} \text { (ePTFE with one side } \\
\text { macropored, the other side micropored) }\end{array}$ & WLGore \\
\hline $\begin{array}{l}\text { Dual Mesh Plus }{ }^{\circledR} \text { (ePTFE double } \\
\text { layered + clorhexidine, silver carbonade) }\end{array}$ & WLGore \\
\hline Intra Mesh T1 ${ }^{\circledR}$ (polypropylene+ePTFE) & Cousin Biotech \\
\hline Intra Mesh W3 ${ }^{\circledR}$ (Polyester + dimetyl siloxane) & Cousin Biotech \\
\hline Proceed Mesh ${ }^{\circledR}$ (polypropylene+ePTFE) & Ethicon \\
\hline Omyra mesh ${ }^{\circledR}$ (double sided ePTFE, cPTFE) & Braun \\
\hline
\end{tabular}

a graft conducted at the free borders of the patch, particularly at the symphysis pubis. Recurrences occur not only due to the mesh structure but also due to extracellular matrix (proteoglicans, heparan sulfate, chondroitin sulfate, ketaran sulfate, hyaluronic acid, collagen, elastin, fibronectin, laminin, etc.) disturbances (Marfan and Ehlers-Danlos syndromes, dermatolisis, osteogenesis imperfecta), smoking, age, and genetic factors (6). Normal wound healing takes place when immature collagen Type-3 transforms into mature Type-1 collagen. Placement of meshes slows down this collagen maturation process. There was a decrease in the collagen Type-1/Type- 3 rate in $70 \%$ of the specimens taken from cases where scar healing was delayed after mesh application. This disproportion is the factor that decreases the tensile force (13). Recurrences due to the structure of patches and long-term degradation are also possible. In the long-term, degradation can be observed more frequently in lightweight meshes (PET or ePTFE). In heavyweight meshes, even though it is relatively seen less, with time, there may be some tearing in the mid-area $(14,15)$.

\section{Shrinkage}

According to Le Blanc (16), shrinkage occurs when, during progress of the fibroblastic phase, fibrosis shrinks the mesh tissue 
by embodying it. Le Blanc also reported that this mechanism decreased the original size of meshes by approximately $40 \%$. Amid's radiological follow-ups, on the other hand, reported the shrinkage level as 20\% (17).

Polypropylene heavyweight meshes, by the secondary host's chronic inflammatory response to the foreign object reaction, prevent the transition into the proliferation phase where the scar tensile force takes place (18). For this reason, although 20-94\% shrinkage can be detected in Polypropylne-based heavyweight meshes, there is much less shrinkage in lightweight meshes with a lesser fibrotic reaction (Vypro-2: 29\%, Ultrapro: <5\%) (13).

After the mesh shrinkage phenomenon was noticed, size of the meshes to be used in hernia repair has become the center of discussions. As much as it was argued that the mesh should be $5 \mathrm{~cm}$ wider than each border of the hernia defect, Pelissier asserted that the mesh size should be limited to $200 \mathrm{~cm}^{2}$ for preperitoneal laparoscopic procedures and $80 \mathrm{~cm}^{2}$ for the Lichtenstein procedure, and for young patients, only those meshes large enough to cover the defect should be used (12). In parallel to this, Pelissier also indicated that, a large dissection applied on a "large" mesh increases the shrinkage risk by causing more hematomas (5\%) and seroma (12\%), and in fact, this fibrosis can also embody the neighboring iliac vessels and the bladder (12). Furthermore, it was claimed that shrinkage, particularly in polyproylene mesh applications, could vary depending on the "the area it was placed"; and in incisional hernias, shrinkage is less for the sublay meshes but more for onlay meshes (19).

It is suggested that, in determining the meshes, fixation with the surgical stapler is 2.5 times weaker compared with suture fixation (20).

\section{Chronic Pain}

Although neuropathy-related pain develops at an early phase, chronic pain arises within the first year after mesh placement. This pain is explained by granulomas, which are developed due to the foreign object reaction, compressing or damaging small nerve fibers. Pain is stronger in heavyweight meshes compared with lightweight ones (40\% for polypropylene, 6\% for Vypro) (8).

Tissue sealants or cyanoacrylate-type sealants, which have recently come into use, decrease neurovascular injury risk and postoperative pain but also frequently cause the complication of seroma (20).

\section{Infection}

It is more frequent in multifilament meshes. Microbiological studies have particularly isolates Staphylococcus epidermidis.

In general, infection can be found in both types of meshes, but infection is more in heavyweight ones. On the other hand, fistula formation is only reported for the heavyweight meshes (polypropylene). As polypropylene meshes can cause serious adhesions and fistulas when intraperitoneally placed, the use of ePTFE is suggested, and Gore Tex ${ }^{\circledR}$, a modified version of ePTFE, is reported to be more effective. Recently, to take advantage of the high endurance of heavyweight meshes, a side of polypropuylene meshes is covered with protective films (Proceed ${ }^{\oplus}$, Parietene Composite ${ }^{\circledR}$ ) or adhesion-preventive polymer PVDF (Dyna Mesh ${ }^{\circledR}$ ) to make them more suitable for bowel contact. Prophylactic antibiotic use does not prevent mesh infection. The Dual
Mesh Plus ${ }^{\circledR}$ product is soaked in silver and chlorhexidin, but the results have not met the expectations (21).

\section{Calcification/Impaired Structure}

It was observed in heavyweight meshes (polypropylene) (some tearing in the mid-area over time) or in ePTFE. There are currently no reports for large porous meshes (14).

\section{Seroma}

It may develop in all types of meshes, but the risk increases when heavyweight meshes are used.

\section{CONCLUSION}

For inguinal hernia repairs, meshes should be chosen based on the hernia type. Even though large porous lightweight meshes have lower resistance to tension, they seem superior to other mesh types because they are more flexible and cause less discomfort.

It was concluded that, in case of infection, monofilament, large porous, absorbable lightweight meshes or biological grafts and, for intra-abdominal procedures, composite meshes with a side covered with adhesion-preventive barrier should be convenient.

Peer-review: Externally peer-reviewed.

Author contributions: Concept - D.G.; Design - D.G., F.N.K.; Supervision - F.N.K.; Resource - D.G.; Materials - D.G.; Data Collection and/or Processing - D.G.; Analysis and/or Interpretation - D.G., F.N.K; Literature Search - D.G.; Writing - D.G.; Critical Reviews - F.N.K.; Other - D.G.

Acknowledgements: We would like to thank to Burak Gönüllü for his active contribution in the translation of this article.

Conflict of Interest: No conflict of interest was declared by authors.

Financial Disclosure: The authors declared that this study has received no financial support.

\section{REFERENCES}

1. Dilek ON, Türel KS. The use of mesh in hernia repair and it's complications. J Surg Arts 2009; 2: 1-9.

2. Usher FC, Ochsner J, Tuttle LL Jr. Use of marlex mesh in the repair of incisional hernias. Am Surg 1958; 24: 969-74.

3. Cobb WS, Peindl RM, Zerey M, Carbonell AM, Heniford BT. Mesh terminology 101. Hernia 2009; 13: 1-6. [CrossRef]

4. Cumberland $\mathrm{VH}$. A preliminary report on the use of prefabricated nylon weave in the repair of ventral hernia. Med J Aust 1952; 1: 143-4.

5. Rosch R, Junge K, Schaehtrupp A, Klinge U, Klosterhalfen B, Schumpelick $V$. Mesh implants in hernia repair.Inflammatory cell response in a rat model. Eur Surg Res 2003; 35: 161-6. [CrossRef]

6. Klosterhalfen $B$, Junge $K$, Klinge $U$. The lightweight and large porous mesh concept for hernia repair. Exper Rev Med Devices 2005; 2: 103-17. [CrossRef]

7. Bringman S, Conze J, Cuccurullo D, Deprest J, Junge K, Klosterhalfen B, et al. Hernia repair: The search for ideal meshes. Hernia 2010; 14: 81-7. [CrossRef]

8. Brown CN, Finch JG. Which mesh for hernia repair? Ann R Coll Surg Engl 2010; 92: 272-8. [CrossRef]

9. Junge K, Rosch R, Klinge U, Saklak M, Klosterhalfen B, Peiper C, et al. Titanium coating of a polypropylene mesh for hernia repair: Effect on biocompatibility. Hernia 2004; 9: 115-9. [CrossRef]

10. Junge $K$, Rosh R, Krones CJ, Klinge U, Mertens PR, Lynen P, et al. Influence of polyglecaprone 25(Monocryl) supplementation on the biocompatibility of a polypropylene mesh for hernia repair. Hernia 2005; 9: 212-7. [CrossRef] 
11. Gilbert Al. Sutureless repair of inguinal hernia. Am J Surg 1992; 163: 331-9. [CrossRef]

12. Pelissier EP. Inguinal hernia: The size of the mesh. Hernia 2001; 5: 169-71. [CrossRef]

13. Klosterhalfen $B$, Hermanns $B$, Rosch $R$, Junge K. Biological response to mesh. Eur Surg 2003; 35: 16-20. [CrossRef]

14. Langer $\mathrm{C}$, Neufang $\mathrm{T}$, ley $\mathrm{C}$, Liersh $\mathrm{T}$, Becher $\mathrm{H}$. Central mesh reccurence after incisional hernia repair with Marlex-are the meshes strong enough? Hernia 2001; 5: 164-7. [CrossRef]

15. Hollinsky C, Sandberg S, Koch T, Seidler S. Biomechanical properties of lightweight versus heavyweight meshes for laparoscopic inguinal hernia repair and their impact on recurrence rates. Surg Endosc 2008; 22: 2679-85. [CrossRef]

16. Le Blanc A. Complications associated with the plug-and-patch method of inguinal herniorraphy. Hernia 2001; 5: 135-8. [CrossRef]
17. Amid PK. Classification of biomaterials and their related complications in abdominal wall hernia surgery. Hernia 1997; 1: 15-21. [CrossRef]

18. Schulz DD, Czeczko NG, Malafaia O, Schulz GJ, Czeczko LE, Garcia LS, et al. Evaluation of healing prosthetic materials polyester mesh resorbable film and collagen elastin matrix/polypropylene used in rabbits abdominal wall defects. Acta Cir Bra 2009; 24: 476-83. [CrossRef]

19. Garcia Ulena MA, Vega Ruiz V, Diaz Godoy A, Báez Perea JM, Marín Gómez LM, Carnero Hernández FJ, et al. Differences in polypropylene shinkage depending on mesh position in an experimental study. Am J Surg 2007; 193: 538-42. [CrossRef]

20. Doctor HG. Evaluation of various prosthetic materials and newer meshes for hernia repairs. J Minim Access Surg 2006; 2: 110-6. [CrossRef]

21. Leblanc KA. Fıtık onarımı için prostetik biyomateryaller. In: Kingsnorth AN, Leblanc KA, editors. Management of abdominal hernias. 1.st ed. İstanbul: Nobel Tıp Kitapevleri; 2007. p.77-103. 